\title{
Novel Regulation of Adenylyl Cyclases by Direct Protein-Protein Interactions: Insights from Snapin and Ric8a
}

\author{
Shyi-Chyi Wang Jiun-Tsai Lin Yijuang Chern \\ Institute of Biomedical Sciences, Academia Sinica, Taipei, Taiwan, ROC
}

Key Words

Adenylyl cyclase $\cdot$ cAMP $\cdot$ Ric8a $\cdot$ Snapin $\cdot$ Calcium

\begin{abstract}
Adenosine $3^{\prime}, 5^{\prime}$-cyclic mononucleotide (cAMP) is one of the most important second messengers which govern cellular signal transductions. Adenylyl cyclases (ACs), which are cAMP-synthesizing enzymes, are responsible for cAMP production during extracellular stimulation or intracellular metabolic alteration. In mammals, 9 transmembrane ACs and 1 soluble AC have been identified and characterized. In the past 2 decades, the biochemical properties of these ACs have been extensively studied. Genetic knockout and transgenic overexpression mouse models of at least 6 ACs have been produced, revealing their specific in vivo functions. An awareness of the importance of microdomains and cellular compartmentation for selective $\mathrm{AC}$ regulation has also been fostered. Most intriguingly, a handful of novel AC-binding proteins have recently been reported. Selective binding of ACs to their binding partners allows the precise compartmentalization of ACs and permits unique regulation. Based on recent studies on AC-interacting proteins (particularly Snapin and Ric8a), this review focuses on the importance and possible involvement of AC-interacting proteins in (1) the association of the CAMP signaling pathway with various cellular machineries and (2) the coordination of tightly regulated CAMP signaling by other signaling molecules.
\end{abstract}

Copyright $\odot 2009$ S. Karger AG, Basel

\section{KARGER}

Fax +41613061234 E-Mail karger@karger.ch www.karger.com (c) 2009 S. Karger AG, Basel

$1424-862 X / 09 / 0173-0169 \$ 26.00 / 0$

Accessible online at:

www.karger.com/nsg

\section{Introduction}

Adenylyl cyclases (ACs) are a family of enzymes which produce adenosine $3^{\prime}, 5^{\prime}$-cyclic mononucleotide (cAMP) from ATP. To date, 9 transmembrane ACs (tmACs) and 1 soluble adenylyl cyclase (sAC) have been cloned and characterized in mammals [1-6]. All tmACs possess 3 cytosolic domains (designated the $\mathrm{N}, \mathrm{Cla} / \mathrm{b}$ and $\mathrm{C} 2$ domains; fig. 1) which are separated by 2 sets of 6 transmembrane clusters (M1 and M2) $[1,4,7,8]$. The C1a and C2 domains form the catalytic core and are highly homologous (with $50-90 \%$ similarity in amino acids) among the $9 \mathrm{tmAC}$ members [9]. The catalytic core complex can be activated by forskolin or Gs $\alpha$ proteins [10-12] by enhancing the interaction between the C1a and $\mathrm{C} 2$ domains and by stabilizing the $\mathrm{C} 1 \mathrm{a}-\mathrm{C} 2$ catalytic core complex [9]. In addition, several $\mathrm{AC}$ isoforms (type $\mathrm{I} A C, \mathrm{ACl}$; type $\mathrm{V}$ AC, AC5 and type VI AC, AC6), but not all, can be inhibited by Gi $\alpha$ [13]. The tmACs can also be regulated by a wide variety of signaling molecules, including $G$ protein $\beta \gamma$ subunits, regulators of $G$ protein signaling (RGSs), $\mathrm{Ca}^{2+}$, calmodulin, protein kinases (e.g. protein kinase A, protein kinase $\mathrm{C}$, tyrosine kinases and $\mathrm{Ca}^{2+} /$ calmodulindependent protein kinase II), phosphatases and nitric oxide in isozyme-specific manners [1, 14-29]. tmACs can thus function as molecular coincidence detectors which integrate positive and negative signals that act directly through stimulation of $G$ protein-coupled receptors (GPCRs) or indirectly via intracellular signaling path-

Dr. Yijuang Chern

Institute of Biomedical Sciences

Academia Sinica

Taipei 11529, Taiwan (ROC)

Tel. +886 22652 3913, Fax +88622782 9143, E-Mail bmychern@ibms.sinica.edu.tw 
ways [30]. Besides classical regulatory mechanisms mediated by trimeric $\mathrm{G}$ proteins or phosphorylation, ACs can also be modulated by direct protein-protein interactions which highlight the importance of binding partners and microdomains in the selectivity of AC members.

Besides the 9 tmACs, only 1 mammalian sAC has been reported. Its structure is distinct from those of the tmACs, and it does not respond to standard activators (i.e. forskolin or Gs $\alpha$ ) of tmACs. Instead, the sAC can be directly activated by $\mathrm{CO}_{2} / \mathrm{HCO}_{3}$ and $\mathrm{Ca}^{2+}[3]$. Expression of the sAC was first identified in testes and was later also found to be expressed in many other tissues (e.g. in the brain and kidneys). It is of great interest that multiple proteins (including some involved in energy utilization and membrane signal transduction) are closely associated with the sAC [31]. Specifically, the coexistence of a sperm-specific $\mathrm{Na}^{+} / \mathrm{H}^{+}$exchanger in the same signaling complex is vital for bicarbonate-mediated activation of the sAC [32]. In renal epithelial cells, the sAC is closely associated with the vacuolar proton-pumping ATPase and is thus believed to modulate renal distal proton secretion [33]. Similar to tmACs, direct protein interactions are also one of the key modulatory modes for the sAC.

It is generally accepted that microdomains and cellular compartmentalization are critical factors determining the specific functions of ACs [14]. In the past few years, several intriguing AC-binding proteins, which provide novel associations with either new signaling molecules or components of other cellular machineries, have been reported. This review focuses on recent findings of novel AC-binding proteins which permit novel regulation and functions of ACs via direct protein-protein interactions.

\section{Pathophysiological Functions of ACs}

Due to the availability of transgenic overexpression or knockout mice of several AC isozymes, knowledge regarding the specific functions of $\mathrm{AC}$ isozymes has rapidly accumulated in the past decade. Selective functions of ACs revealed by genetic mouse models are listed in table 1 . This is by no means a comprehensive list, but an illustration of how discriminating the functions of these ACs can be in vivo.

It has long been believed that diverse tissue expression profiles and/or selective subcellular localizations of ACs enable AC isozymes to mediate their specific pathophysiological functions. For example, type III AC (AC3) is mainly expressed in olfactory neurons [34-36] and was
Table 1. Selective pathophysiological functions of ACs revealed by genetic mouse models

\begin{tabular}{|c|c|c|}
\hline $\begin{array}{l}\text { AC iso- } \\
\text { zyme }\end{array}$ & Pathophysiological functions & Reference(s) \\
\hline \multirow[t]{8}{*}{$\mathrm{AC} 1$} & Learning and memory & $116-118$ \\
\hline & Glutamate-induced neuronal death & 46 \\
\hline & Insertion of the AMPA receptors into & \\
\hline & synapses & 119 \\
\hline & Opiate dependence & 120 \\
\hline & Pain & 121 \\
\hline & Pattern formation in the cortex & 122 \\
\hline & Circadian rhythms & 123 \\
\hline \multirow[t]{2}{*}{ AC3 } & Odorant-induced transduction cascade & $37-39$ \\
\hline & Male fertility & 124 \\
\hline \multirow[t]{8}{*}{ AC5 } & Dopaminergic signals and motor & \\
\hline & functions & 40,125 \\
\hline & Cardiac stress & $49,50,56$ \\
\hline & Sympathetic and parasympathetic & \\
\hline & regulation of the heart & 126 \\
\hline & Action of morphine & 127 \\
\hline & Pain & 128 \\
\hline & Life span & 129 \\
\hline AC6 & Left ventricular function & $51-54$ \\
\hline \multirow[t]{4}{*}{ AC8 } & Learning and memory & 130 \\
\hline & Opiate withdrawal & 120 \\
\hline & Pain & 121 \\
\hline & Anxiety & 131 \\
\hline sAC & Male fertility & $42,132,133$ \\
\hline
\end{tabular}

found to mediate the odorant-induced transduction cascade and behavior [37-39]. AC5 is heavily expressed in the striatum. It is therefore not surprising that genetic removal of AC5 impairs the function of a striatal GPCR (the D2 dopamine receptor) [40]. Likewise, the sAC was found to be highly expressed in testes. To date, the most prominent function of sAC found so far is in sperm fertilization [41-43]. Another interesting example is the apparent overlapping roles of $\mathrm{ACl}$ and type VIII AC (AC8) in learning and memory. $\mathrm{ACl}$ and $\mathrm{AC} 8$ are $\mathrm{Ca}^{2+} / \mathrm{calmod}-$ ulin (CaM)-activated ACs, both of which exist in the hippocampus and have been demonstrated to critically contribute to long-term memory [44]. More recent studies showed that $\mathrm{AC} 1$ and $\mathrm{AC} 8$ are selectively located in the postsynaptic density and presynaptic active zones, respectively [45]. Consistent with the postsynaptic distributions, genetic removal of $\mathrm{AC1}$ (but not AC8) eliminates the cortical lesion induced by an intracortical injection of $\mathrm{N}$-methyl-D-aspartic acid [46]. Taken together, AC1 and AC8 play different functional roles due to their distinct localizations. 
Table 2. Interacting proteins of ACs

\begin{tabular}{|c|c|c|c|c|}
\hline $\begin{array}{l}\mathrm{AC} \\
\text { isoform }\end{array}$ & Interacting protein & $\begin{array}{l}\text { Interacting } \\
\text { domain(s) } \\
\text { of AC }\end{array}$ & Function & Reference(s) \\
\hline \multirow[t]{4}{*}{ AC5 } & PAM & $\mathrm{C} 2$ & Inhibiting $\mathrm{AC}$ activity & 73,134 \\
\hline & RGS2 & $\mathrm{C} 1$ & Inhibiting AC5 activity & 19,74 \\
\hline & AKAP79/150 & n.d. & Mediating the PKA-evoked inhibition of AC5 & 75 \\
\hline & Ric8a & $\mathrm{N}$ & Inhibiting AC5 activity & 89 \\
\hline \multirow[t]{2}{*}{ AC6 } & Snapin & $\mathrm{N}$ & Preventing the PKC-mediated inhibition of AC6 activity & 80 \\
\hline & AKAP79/150 & n.d. & Mediating the PKA-evoked inhibition of AC6 & 75 \\
\hline \multirow[t]{2}{*}{ AC8 } & Calmodulin & $\mathrm{N}, \mathrm{C}$ & Mediating the CCE-evoked stimulation & 78,114 \\
\hline & $\mathrm{PP} 2 \mathrm{~A}-\mathrm{C}$ & $\mathrm{N}$ & Coordinating $\mathrm{Ca}^{2+}$ and cAMP signals & 81 \\
\hline \multirow[t]{2}{*}{ sAC } & $\mathrm{Na}^{+} / \mathrm{H}^{+}$exchanger & n.d. & Mediating the bicarbonate-mediated activation of sAC & 32 \\
\hline & Vascular proton-pumping ATPase & n.d. & Modulating renal distal proton secretion & 33 \\
\hline
\end{tabular}

Trimeric GTP-binding proteins bind multiple ACs and are therefore not listed here. n.d. = Not defined.

The diverse functions of 2 calcium-inhibitable ACs (i.e. AC5 and AC6), however, are rationalized with greater difficulty. AC5 and AC6 are 2 major cardiac ACs. They both produce cAMP during stimulation of $\beta$-adrenergic receptors and have been implicated in cardiac functions for years [47-49]. Homology between AC5 and AC6 is strikingly high. The identity in amino acids of the catalytic cores (C1 and C2) of rat AC5 and AC6 is nearly $85 \%$. Surprisingly, studies using knockout and transgenic overexpression mouse models have suggested that AC5 and AC6 function in opposite directions during cardiac stress $[50,51]$. Overexpression of AC6 enhances the left ventricular function in heart failure [52-54]. Moreover, expression of AC6 in cardiomyocytes elevates cAMP production, ameliorates heart function and prolongs survival in cardiomyopathy [55]. Consistent with the beneficial roles of AC6 in the heart, the genetic inactivation of AC6 impairs the calcium response and causes severer cardiac defects [51]. In contrast, genetic removal of AC5 is beneficial and suppresses myocardial apoptosis by elevating Bcl-2 during heart failure $[49,56]$. The effects of AC6 and AC5 deletion on several cardiac signaling parameters [e.g. SERCA2a affinity for $\mathrm{Ca}^{2+}$, phosphorylation of phospholamban and protein kinase A (PKA) activity] also stunningly differ [51]. It is noteworthy that the beneficial effects of AC6 on failing hearts cannot be explained by simply elevating the intracellular cAMP level because chronic elevation of the cAMP content has been shown to increase mortality in patients with heart failure $[57,58]$. AC6 thus might exert its advantageous effect via a pathway which is independent of cAMP generation [51,
$55,59]$. It was proposed that the beneficial effect of AC6 in the heart might be mediated by regulating the activating transcription factor 3 and phospholamban in a cAMPindependent but phosphatase-dependent pathway [48, 55]. Selective cellular compartmentalization of cardiac AC6 might also contribute to its cAMP-independent functions. In the latter case, further investigation of the signal complexes that (1) comprise the binding partners (e.g. Snapin) of AC6 and (2) regulate the CAMP and $\mathrm{Ca}^{2+}$ interplay might provide important clues [6,59-61].

\section{Interacting Proteins of ACs}

The 2 best-characterized binding proteins of tmACs are the $\alpha$ subunits of trimeric GTP-binding proteins. The stimulatory $\mathrm{Gs} \alpha$ and inhibitory Gi $\alpha$ respectively bind to the $\mathrm{C} 2$ and $\mathrm{C} 1$ domains of ACs $[9,62]$. The heterotrimeric G $\beta \gamma$ complex also regulates the activities of tmACs. Specifically, Gßy inhibits $\mathrm{AC} 1$ and $\mathrm{AC} 8$, while activating type II AC (AC2) and type IV AC (AC4) [21, 63]. One of the major binding domains of G $\beta \gamma$ in tmACs appears to

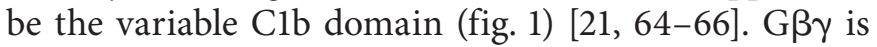
also associated with the $\mathrm{C} 2$ domain of AC2 [67, 68]. Although G $\beta 2$ clearly binds to a relatively homologous region in the regulatory $\mathrm{N}$ terminus of both $\mathrm{AC} 5$ and AC6, the effects of G $\beta \gamma$ on AC5 and AC6 remain controversial and might depend on the cellular signaling conditions [69-72].

Besides the trimeric GTP-binding proteins, additional binding proteins of tmACs have been reported (table 2). 


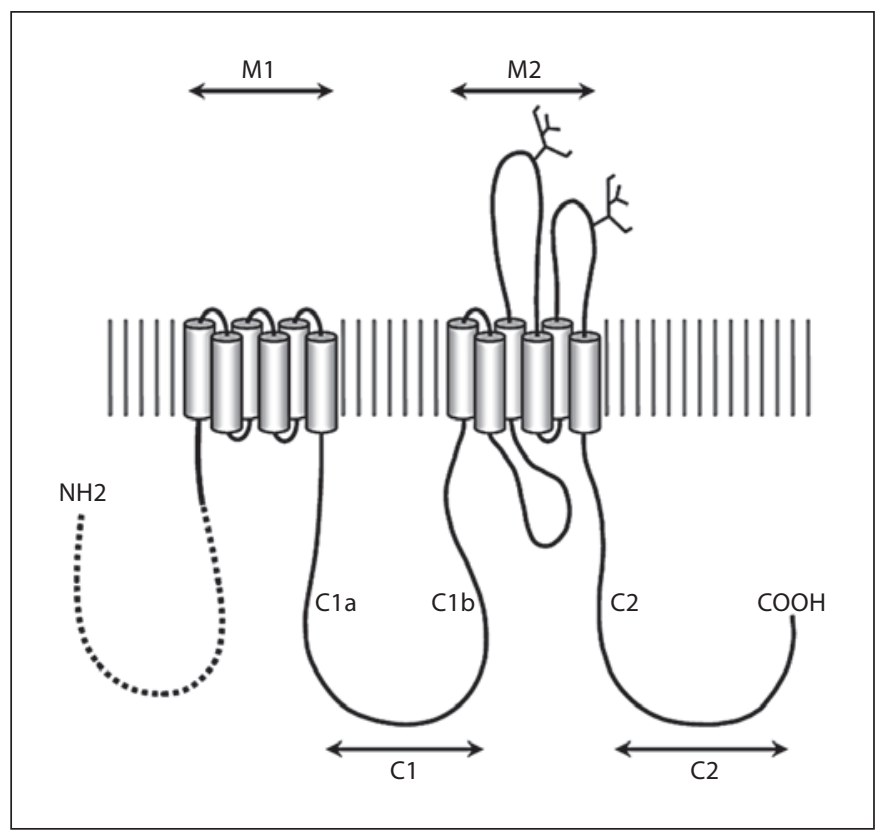

Fig. 1. Schematic representation of tmACs. All tmACs possess 3 large cytosolic domains (designated are the $\mathrm{N}, \mathrm{Cla} / \mathrm{b}$ and $\mathrm{C} 2 \mathrm{do}-$ mains) that are separated by 2 sets (M1 and M2) of 6 transmembrane clusters. The $\mathrm{C} 1 \mathrm{a}$ and $\mathrm{C} 2$ domains form the catalytic core. The $\mathrm{N}$ terminus domains are diverse in length (ranging from 28 to 239 aa, table 3 ) and in amino acid sequence.

Table 3. Distinct sizes of the $\mathrm{N}$ termini of tmACs

\begin{tabular}{lcl}
\hline $\begin{array}{l}\text { AC } \\
\text { isozyme }\end{array}$ & $\begin{array}{l}\text { Length of the N } \\
\text { terminus (aa) }\end{array}$ & $\begin{array}{l}\text { Accession No. } \\
\text { (GenBank) }\end{array}$ \\
\hline AC2 & 44 & $\begin{array}{l}\text { M80550. Gb_Ro } \\
\text { AC4 }\end{array}$ \\
AC7 & 38 & $\begin{array}{l}\text { M80633. Gb_Ro } \\
\text { U12919. Gb_Ro }\end{array}$ \\
AC5 & 239 & M96159. Gb_Ro \\
AC6 & 163 & M96160. Gb_Ro \\
AC1 & 62 & M25579. Gb_Om \\
AC8 & 178 & L26986. Gb_Ro \\
AC3 & 77 & M55075. Gb_Ro \\
AC9 & 120 & U30602. Gb_Ro \\
\hline
\end{tabular}

For example, the protein associated with Myc (PAM) was found to interact with AC5. By binding to its $\mathrm{C} 2$ domain, PAM inhibits the catalytic activity of AC5 and a few other ACs, but not all ACs (e.g. not AC2) [73]. In addition, regulators of the $G$ protein signaling 2 (RGS2) were shown to bind to the $\mathrm{C} 1$ domain of $\mathrm{AC} 5$ and inhibit its activity
[19]. Since RGS2 also interacts with other ACs, this RGS2mediated inhibition might be a general regulatory mode for other tmACs [74]. Using an affinity purification method, an A-kinase anchoring protein (AKAP79/150) was found to form a complex with AC5 and AC6 [75]. AKAP79/150 is a multivalent scaffolding protein which is associated with many signaling molecules (such as PKA and PKC) that are capable of regulating tm ACs [76]. In particular, both AC5 and AC6 can be suppressed by PKA $[18,77]$. Interacting with AKAP79/150 brings PKA close to these $2 \mathrm{ACs}$ and creates a negative feedback loop for the tight control of cAMP production by AC5 and AC6 during stimulation [75].

The N-terminal domains of the $9 \mathrm{tmACs}$ are diverse in both length and amino acid sequences [72]. AC4 has the shortest $\mathrm{N}$ terminus [28; amino acids (aa)], while AC5 has the longest $\mathrm{N}$ terminus (239 aa) (table 3; fig. 1). Accumulating evidence has demonstrated that $\mathrm{N}$ termini of tmACs usually serve as regulatory domains [3, 78-81]. To date, a handful of $\mathrm{N}$-terminus-interacting proteins which bind to $3 \mathrm{tmACs}$ with long $\mathrm{N}$ termini (i.e. AC5, AC6 and AC8) have been characterized. Due to the divergent nature of these $\mathrm{N}$ termini, regulation mediated by $\mathrm{N}$-terminus-binding proteins is usually isozyme specific [ $[79$, 80].

\section{Interaction with Ric8a Allows the}

Receptor-Independent Regulation of AC5

AC5 has the longest $\mathrm{N}$ terminus among all 9 tmACs (table 3). The first reported binding partner of AC5's N terminus was $\mathrm{G} \beta 2$ as described above [71]. Interestingly, the binding region (aa 77-151) of G $\beta 2$ is where the N-terminal domains of AC5 and AC6 share some homology [72]. Binding to G $\beta 1$ therefore affects the activities of both AC5 and AC6 [71].

The second reported protein which binds to the $\mathrm{N}$ terminus of AC5 is Ric8a, a guanine nucleotide exchange factor [79]. Ric8a was first reported to mediate the Gq $\alpha$ responsible signaling pathway for neurotransmitter release in nematodes and was subsequently shown to function as a receptor-independent guanine exchange factor by binding to numerous $\mathrm{G} \alpha$ proteins [82]. Briefly, Ric8a is known to bind to the GDP-bound form of the G $\alpha$ protein and promote the exchange of GDP and GTP. Interactions between AC5 and Ric8a lead to suppression of the cyclase activity of AC5 via a Gi $\alpha$ protein-dependent pathway. Most intriguingly, this inhibition of AC5 by Ric8a requires no activation of the GPCR. In addition, Ric8a has been shown to enhance $\beta \gamma$-evoked signaling [47]. Since G $\beta \gamma$ is also known to modulate AC5 [69, 71], 
it will be of great interest to further elucidate the functional interactions between Ric8a and G $\beta \gamma$ in regulating AC5.

As detailed above, AC5 is considered to be harmful to cardiac function during cardiac stress because the hearts of AC5-null mice express higher levels of Bcl-2 during pressure overload [49]. Suppression of AC5 is considered to be beneficial by inhibiting myocardial apoptosis during heart failure. AC5-selective inhibitors are therefore potential drugs for treating cardiac myocyte apoptosis evoked by excessive $\beta$-adrenergic stimulation [56]. Although the physiological relevance of the AC5/Ric8a complex is currently unknown, it was interesting that the level of Ric8a was elevated $48 \mathrm{~h}$ after an acute myocardial infarction induced by left coronary artery ligation [83]. Since Ric8a suppresses the overactivation of AC5 [79], the increase in Ric8a expression might play a protective role during cardiac stress. Potential clinical implications of the AC5/Ric8a complex are worthy of further exploration.

\section{Snapin Links AC6 to a Wide Variety of Cellular Apparatuses}

The $\mathrm{N}$ terminus of AC6 is a relatively large cytosolic domain of 160 aa. It interacts with the Cla domain and plays an important role in the Gi $\alpha$-mediated inhibition of AC6 [84]. Moreover, phosphorylation of the $\mathrm{N}$ terminus of AC6 at $\mathrm{Ser}^{10}$ by PKC is responsible for the PKCevoked inhibition of AC6 [16, 72]. The first protein identified to interact with the $\mathrm{N}$ terminus of AC6 was Snapin [60]. Snapin was originally found to be located on synaptic vesicle membranes and to primarily be involved in the exocytosis process for neurotransmitter release [85]. It interacts with the assembled soluble N-ethylmaleimide-sensitive fusion protein attachment protein receptor (SNARE) core complex as well as with isolated SNAP25 through its C-terminal coiled-coil domain [85]. Moreover, Snapin is implicated as being a synapsespecific PKA target with an important regulatory role in neurotransmitter release [85-88]. It is interesting to note that Snapin might have a more general role in SNARE-mediated fusion events, since it has a broad tissue distribution and predominantly cytoplasmic localization $[89,90]$. More recent studies have suggested that Snapin may also be involved in intracellular vesicle trafficking. The interaction between AC6 and Snapin provides a fine-tuning mechanism for the cAMP production system via the vesicle-transporting machinery in the brain.

Novel Regulation of Adenylyl Cyclases
It is intriguing that at least 20 binding proteins of Snapin were found in the past decade, indicating that Snapin might be a critical scaffold protein linking a wide variety of cellular machineries with the vesicle-transporting system (table 4). Some of these Snapin-interacting proteins are associated with neurosecretion and biogenesis of the endosomal-lysosomal system [88, 91-93]. Other Snapin-interacting proteins include a regulator of G protein signaling 7 [94], TPR/MET tyrosine kinase [95], dysbindin [96], casein kinase $1 \delta$ [97], a UT-A1 urea transporter [98], the Exo70 subunit of the exocyst [99], members of the transient receptor potential canonical (TRPC) family $[93,100]$ and ryanodine receptors (RyRs) [61]. Among the Snapin-interacting proteins, RyRs are of greatest interest because they are calcium channels located in the endoplasmic reticula (ER) and are major players in calcium-induced calcium release in animal cells. Snapin binds to all 3 forms of RyRs [61]. The AC6/ Snapin/RyR complex might allow AC6 to be efficiently suppressed by extracellular calcium influx as well as by intracellular calcium release (fig. 2). By binding to Snapin, AC6 might regulate the trafficking of important membrane proteins in multiple organs. The role of AC6 in Snapin-mediated vesicle fusion might be complex and needs to be carefully investigated in each specific cell type. It is possible that AC6 might manipulate vesicle fusion events and the tight interaction between $\mathrm{Ca}^{2+}$ and cAMP by (1) producing cAMP and (2) tethering a group of calcium-sensitive molecules to the site of action. In cells expressing AC6 (fig. 2a), the stimulation of a Gs $\alpha$ protein-coupled receptor (Gs $\alpha-\mathrm{R})$ activates AC6, triggers cAMP production and subsequently activates PKA. It is noteworthy that AC6 was shown to be associated with AKAP150 and likely coexists with PKA [75]. Activation of PKA then leads to the phosphorylation of (1) Snapin enhancing its ability to interact with SNAP25 [85] and modulating vesicle fusion events, (2) receptors or channels (e.g. AMPA GluR1 and the L-type calcium channel) increasing their activities and triggering more calcium to enter the cells [101-104], (3) the RyR, prolonging its activity [105] and thus promoting greater calcium release from ryanodine-sensitive intracellular stores and (4) AC6 itself, efficiently terminating cAMP production [18]. In the presence of AC6 signalosomes, activation of the Gs $\alpha$-R might efficiently potentiate calcium-mediated responses at multiple steps by PKAevoked phosphorylation. The impaired calcium response found in cardiac myocytes that contain no AC6 supports the above-mentioned concept [51]. Due to the apparent increase in efficiency, this fine-tuning mode of 
Table 4. Snapin-interacting proteins

\begin{tabular}{|c|c|c|c|c|}
\hline Protein & $\begin{array}{l}\text { Interacting domain } \\
\text { of Snapin }\end{array}$ & \multicolumn{2}{|c|}{ Function } & $\begin{array}{l}\text { Refer- } \\
\text { ence }\end{array}$ \\
\hline SNAP25 & C terminus (aa $79-136)$ & \multicolumn{2}{|c|}{ Synaptic vesicle exocytosis } & 85 \\
\hline SNAP23 & C terminus (aa 79-136) & \multicolumn{2}{|c|}{ Nonneuronal vesicle exocytosis } & 89 \\
\hline RGS7 & n.d. & \multicolumn{2}{|c|}{ Synaptic vesicle exocytosis } & 94 \\
\hline AC6 & aa $33-51$ & \multicolumn{2}{|c|}{ Prevention of the PKC-mediated inhibition of AC6 } & 60 \\
\hline TRPV1 & n.d. & \multicolumn{2}{|c|}{$\begin{array}{l}\text { Inhibition of the PKC-induced potentiation of TRPV1 } \\
\text { channel activity }\end{array}$} & 135 \\
\hline BLOS1 & n.d. & \multirow{3}{*}{\multicolumn{2}{|c|}{ n.c. }} & 92 \\
\hline BLOS2 & & & & \\
\hline BLOS3 & & & & \\
\hline Dysbindin-1 & n.d. & \multicolumn{2}{|c|}{ Synaptic vesicle exocytosis } & 96 \\
\hline Cypin & C terminus (aa $81-126$ ) & \multicolumn{2}{|c|}{ Modulation of neuronal processes } & 136 \\
\hline Collectrin & n.d. & \multicolumn{2}{|c|}{ Modulation of insulin exocytosis } & 137 \\
\hline EBAG9 & $\mathrm{N}$ terminus (aa 21-82) & \multicolumn{2}{|c|}{ Exocytosis } & 91 \\
\hline TPR/MET & n.d. & \multicolumn{2}{|c|}{ n.c. } & 95 \\
\hline CK1 $1 \delta$ & C terminus (aa $37-136)$ & \multicolumn{2}{|c|}{ Phosphorylation of Snapin } & 97 \\
\hline GCSF-R & n.d. & \multicolumn{2}{|c|}{ n.c. } & 138 \\
\hline RyR & n.d. & \multicolumn{2}{|c|}{ Sensitization of the RyR at submicromolar concentrations of $\mathrm{Ca}^{2+}$} & 61 \\
\hline Urea transporter UT-A1 & C terminus (aa $81-126)$ & \multicolumn{2}{|c|}{ Enhancement of urea transport activity } & 98 \\
\hline TRPM7 & n.d. & \multicolumn{2}{|c|}{ Modulation of postsynaptic EPSPs } & 93 \\
\hline$\alpha_{1 \mathrm{~A}}-\mathrm{AR}$ & n.d. & \multicolumn{2}{|c|}{$\begin{array}{l}\text { Enhancement of } \alpha_{1} \text { a-adrenoceptor-mediated calcium influx } \\
\text { through TRPC6 }\end{array}$} & 100 \\
\hline TRPC6 & n.d. & \multicolumn{2}{|c|}{$\begin{array}{l}\text { Enhancement of } \alpha_{1} \text { a-adrenoceptor-mediated calcium influx } \\
\text { through TRPC6 }\end{array}$} & 100 \\
\hline Exo70 & C terminus (aa $84-118$ ) & \multicolumn{2}{|c|}{ Modulation of GLUT4 trafficking } & 99 \\
\hline \multicolumn{3}{|c|}{$\begin{array}{l}\text { The functional consequence of the corresponding interaction } \\
\text { is listed. } \\
\text { SNAP25 = Synaptosome-associated 25-kDa protein; RGS7 = } \\
\text { regulators of G-protein signaling 7; AC6 = type VI adenylyl cy- } \\
\text { clase; TRPV1 = vanilloid receptor-1; BLOS1-3 = BLOC subunits } \\
1,2 \text { and } 3 \text { (BLOC-1 = lysosome-related organelle complex-1); } \\
\text { EBAG9 = estrogen receptor-binding fragment-associated gene 9; }\end{array}$} & \multicolumn{2}{|c|}{$\begin{array}{l}\text { CK1 } 1 \delta=\text { casein kinase } 1 \delta \text {; GCSF-R = granulocyte colony-stimulat- } \\
\text { ing factor receptor; RyR = ryanodine receptor; TRPM7 = transient } \\
\text { receptor potential cation channel, subfamily } M \text {, member } 7 ; \alpha_{1 A^{-}} \\
\text {AR = } \alpha_{1 \mathrm{~A}} \text { adrenergic receptor; EPSP = excitatory postsynaptic po- } \\
\text { tential; TRPC = transient receptor potential canonical; GLUT4 = } \\
\text { glucose transporter } 4 ; \text { aa = amino acids; } \text { n.d. = not defined; } \text { n.c. }= \\
\text { not characterized. }\end{array}$} \\
\hline
\end{tabular}

AC6 signalosomes might be critical for the suboptimal stimulation of the Gs $\alpha$-R. In cells expressing other AC isoforms, the Snapin/RyR complex is not in the proximal position of $\mathrm{AC}$ and might not be effectively phosphorylated by PKA, except when activation of the Gs $\alpha$ $\mathrm{R}$ is maximal.

When the actions of $\mathrm{Ca}^{2+}$ are considered, the cAMP/ PKA pathway is expected to be negatively regulated at multiple steps in cells expressing AC6 (fig. 2b). Stimulation of receptors and/or depolarization allows calcium to enter through a membrane receptor/channel $\left(\mathrm{R}_{2}\right)$. An increase of cellular $\mathrm{Ca}^{2+}(1)$ triggers vesicle fusion through the SNARE complex, (2) evokes RyR-mediated $\mathrm{Ca}^{2+}$-induced $\mathrm{Ca}^{2+}$ release, further increasing the cellular $\mathrm{Ca}^{2+}$ level and thus suppressing AC6, and (3) directly suppress- es the activity of AC6, reducing CAMP production and PKA activation. Collectively, the presence of the AC6/ Snapin complex ensures that the cAMP/PKA pathway activated by AC6 is efficiently suppressed by $\mathrm{Ca}^{2+}$ at multiple steps, thereby creating a precisely controlled interplay between cAMP and $\mathrm{Ca}^{2+}$.

Another very interesting class of Snapin-binding partners is the TRPC family (fig. 3). In sympathetic neurons, Snapin binds to a TRPC member (TRPM7) which is located in synaptic vesicles. TRPM7 is a nonselective cationic channel and is inactive unless synaptic vesicles are fused with plasma membranes via the SNARE machinery [93]. In addition, Snapin directly interacts with TRPC6 (a TRPC member) and the $\alpha_{1}$-adrenergic receptor (a GPCR) and subsequently enhances the calcium 


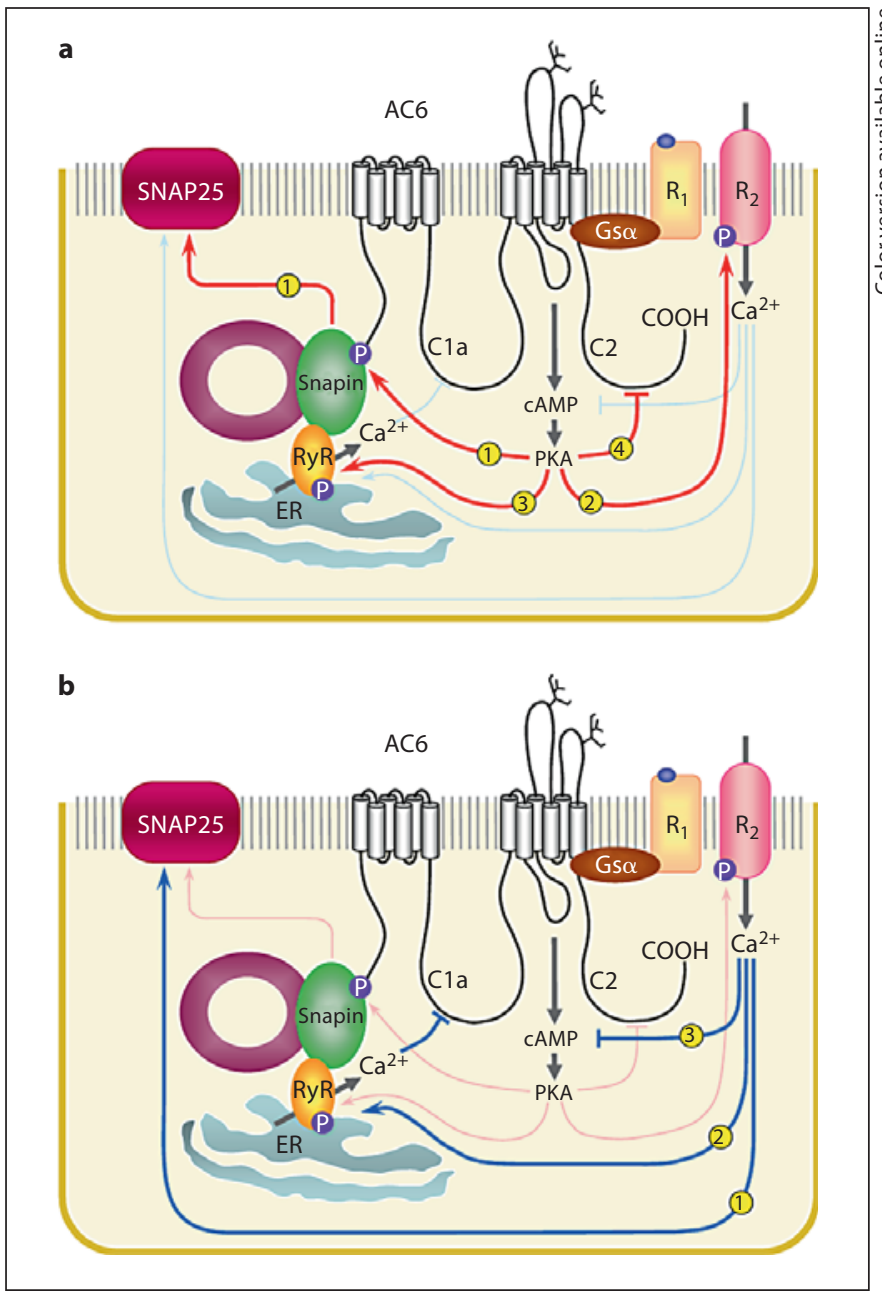

Fig. 2. Schematic diagrams of the potential roles of AC6/Snapin/ RyR complex in the calcium-cAMP interplay. a Actions of PKA: in the presence of an AC6 signalosome, the activation of a Gs $\alpha$ protein-coupled receptor (Gs $\alpha-\mathrm{R})$ efficiently modulates calciummediated responses at multiple steps by PKA-evoked phosphorylation (1-3, please see the text for details). Activated cAMP/PKA might also phosphorylate AC6 itself to rapidly terminate cAMP production (4). This fine-tuning mode of the AC6 signalosome might play a significant role during suboptimal stimulation of the Gs $\alpha-\mathrm{R}$. Only the actions of PKA are illustrated here. $\mathbf{b}$ Actions of $\mathrm{Ca}^{2+}$ : when the actions of $\mathrm{Ca}^{2+}$ are considered, the cAMP/PKA pathway is expected to be negatively regulated at multiple steps in cells expressing AC6. Stimulation of receptors and/or depolarization allows calcium entry through a membrane receptor/channel $\left(\mathrm{R}_{2}\right)$. Increase of cellular $\mathrm{Ca}^{2+}(1)$ triggers vesicle fusion through the SNARE complex, (2) evokes RyR-mediated $\mathrm{Ca}^{2+}$-induced $\mathrm{Ca}^{2+}$ release, further increasing cellular $\mathrm{Ca}^{2+}$ levels and thus suppressing AC6, and (3) directly suppresses the activity of AC6, reducing cAMP production and PKA activation. The presence of the AC6/Snapin/RyR complex ensures that the cAMP/PKA pathway activated by AC6 is efficiently suppressed by $\mathrm{Ca}^{2+}$ at multiple steps. $\mathrm{ER}=$ Endoplasmic reticula; $\mathrm{P}=$ phosphorylation site; $\mathrm{R}_{1}=$ Gs $\alpha$-coupled receptor; $\mathrm{R}_{2}=$ receptors or channels which allow the entry of extracellular calcium.

Novel Regulation of Adenylyl Cyclases

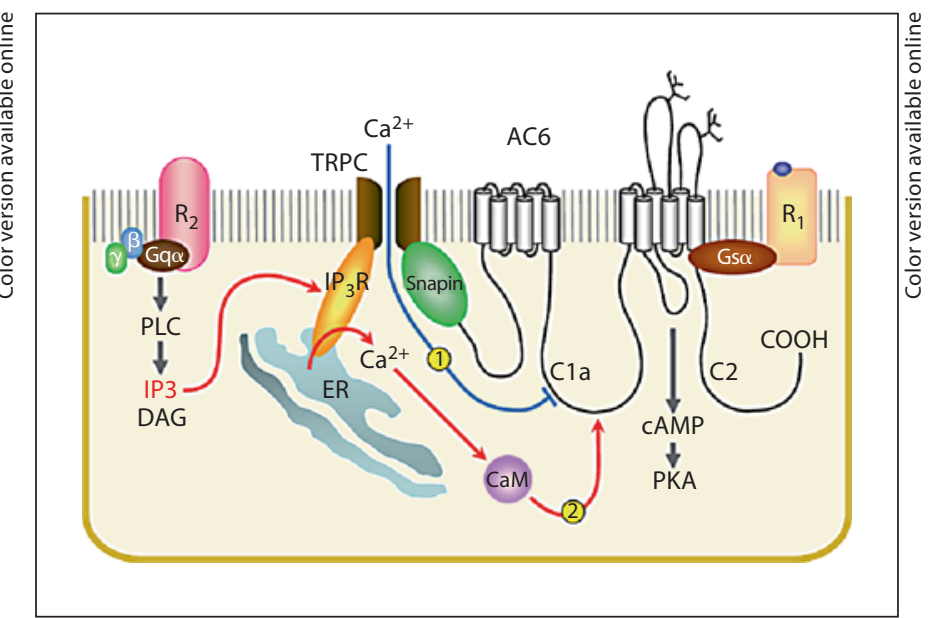

Fig. 3. Schematic diagram of the potential roles of AC6/Snapin/ TRPC complex in a calcium-cAMP interplay. By binding to Snapin, AC6 is expected to be close to TRPC (a major component of CCE) $[110,119]$ and can be effectively inhibited by CCE [23]. In addition, since $\mathrm{IP}_{3} \mathrm{R}$ is also a binding partner of TRPC [111], the AC6/Snapin complex might therefore be associated with TRPC and $\mathrm{IP}_{3} \mathrm{R}$, which allows AC6 to be selectively potentiated during activation of $\mathrm{G} \alpha \mathrm{q}$-coupled receptors [112]. $\mathrm{R}_{1}=\mathrm{Gs} \alpha$-coupled receptor; $\mathrm{R}_{2}=\mathrm{Gq} \alpha$-coupled receptor; $\mathrm{ER}=$ endoplasmic reticula.

influx evoked by receptor-operated $\mathrm{Ca}^{2+}$ channels [100]. Two other TRPC family members (TRPC1 and TRPC3) were also found to interact with Snapin-interacting proteins (e.g. SNAP-25, SNAP-23 and syntaxin-3) [106108]. Taken together, the direct binding of Snapin at its $\mathrm{N}$ terminus brings AC6 to a position proximal to TRPC family members which are involved in capacitative calcium entry (CCE) $[109,110]$. This is of great importance because AC6 can be selectively inhibited by CCE in nonexcitable cells [23]. As TRPC also interacts with inositol 1,4,5-triphosphate receptors $\left(\mathrm{IP}_{3} \mathrm{Rs}\right)$ [111], it is likely that the AC6/Snapin complex might be associated with TRPC and $\mathrm{IP}_{3} \mathrm{R}$. Noteworthy is that since several ACs (e.g. AC5, AC6 and AC8) with different $\mathrm{N}$ termini can be regulated by CCE [112, 113], Snapin-mediated signalosomes (AC6, Snapin, TRPC and $\mathrm{IP}_{3} \mathrm{R}$ ) are less likely to play a major role in CCE-mediated inhibition. Instead, such a protein complex might significantly contribute to G $\alpha$ q-mediated selective potentiation of AC6 (but not AC5) [112].

In addition to the RyR and TRPC family, there are at least 18 more proteins which interact with Snapin (table 4). Through binding to Snapin, AC6 might move through the vesicular transport system to closely associ- 
ate with a wide variety of cellular machineries. The AC6AKAP79/150-PKA complex allows Snapin to tightly control PKA-mediated regulation of the apparatuses that interact with Snapin. Although the most important functions of Snapin signalosomes appear to provide a platform for the interplay between cAMP and $\mathrm{Ca}^{2+}$ as described above, novel cross-talk mechanisms among Snapin-binding proteins are expected to be rapidly unraveled in the near future.

\section{The N Terminus of AC8 Brings Together the Key}

Elements for a cAMP-Signaling Module

The $\mathrm{N}$ terminus of AC8 is of great interest because it is the longest among those of the $3 \mathrm{Ca}^{2+}$-responsive $\mathrm{ACs}$ (AC1, AC3 and AC8; table 3) and plays a critical role in CCE's regulation of AC8 [114]. At least 2 important signal molecules (calmodulin and phosphatase $2 \mathrm{~A}$ ) bind to AC8's $\mathrm{N}$ terminus in a mutually exclusive manner [78, $82,114]$. Dynamic regulation among AC8, calmodulin and phosphatase $2 \mathrm{~A}$ might represent a central step in coordinating cAMP, $\mathrm{Ca}^{2+}$ and protein phosphorylation of major components in the surrounding microdomains [6].

\section{Concluding Remarks}

Almost 2 decades after the first AC was cloned [115], tremendous amounts of information regarding ACs have accumulated. The most exciting findings to date include specific in vivo functions of ACs revealed by genetic mouse models, and the awareness that AC signalosomes tether major players of cAMP modules to appropriate cellular compartments. Searching for novel AC-interacting proteins, particularly those which bind to regulatory domains, has therefore set the stage for identifying novel functions and regulatory mechanisms of ACs. In addition, new genetic mouse models of tissue/cell-specific AC knockout, conditional AC knockout and knockin of AC mutants lacking regulatory domains should provide further understanding of the pathophysiological roles of ACs in the coming decade.

\section{Acknowledgments}

We thank Mr. D.P. Chamberlin for reading and editing the manuscript and Mr. Jui-Ming Chang for artwork/illustrations. This work was supported by grants (NHRI-EX94-9203NI) from the National Health Research Institutes and Academia Sinica, Taipei, Taiwan.

\section{References}

1 Chern Y: Regulation of adenylyl cyclase in the central nervous system. Cell Signal 2000; 12:195-204.

2 Chen Y, Cann MJ, Litvin TN, Iourgenko V, Sinclair ML, Levin LR, Buck J: Soluble adenylyl cyclase as an evolutionarily conserved bicarbonate sensor. Science 2000;289:625628.

-3 Buck J, Sinclair ML, Schapal L, Cann MJ, Levin LR: Cytosolic adenylyl cyclase defines a unique signaling molecule in mammals. Proc Natl Acad Sci USA 1999;96:79-84.

-4 Tang WJ, Gilman AG: Adenylyl cyclases. Cell 1992;70:869-872.

5 Sinha SC, Sprang SR: Structures, mechanism, regulation and evolution of class III nucleotidyl cyclases. Rev Physiol Biochem Pharmacol 2006;157:105-140.

-6 Cooper DM, Crossthwaite AJ: Higher-order organization and regulation of adenylyl cyclases. Trends Pharmacol Sci 2006;27:426431.

-7 Sunahara RK, Dessauer CW, Gilman AG: Complexity and diversity of mammalian adenylyl cyclases. Annu Rev Pharmacol Toxicol 1996;36:461-480.
8 Patel TB, Du Z, Pierre S, Cartin L, Scholich $\mathrm{K}$ : Molecular biological approaches to unravel adenylyl cyclase signaling and function. Gene 2001;269:13-25.

-9 Tesmer JJ, Sunahara RK, Gilman AG, Sprang SR: Crystal structure of the catalytic domains of adenylyl cyclase in a complex with Gsalpha.GTPgammaS. Science 1997;278: 1907-1916.

10 Sunahara RK, Dessauer CW, Whisnant RE, Kleuss C, Gilman AG: Interaction of Gsalpha with the cytosolic domains of mammalian adenylyl cyclase. J Biol Chem 1997;272: 22265-22271.

11 Dessauer CW, Scully TT, Gilman AG: Interactions of forskolin and ATP with the cytosolic domains of mammalian adenylyl cyclase. J Biol Chem 1997;272:22272-22277.

12 Dessauer CW, Gilman AG: The catalytic mechanism of mammalian adenylyl cyclase: equilibrium binding and kinetic analysis of P-site inhibition. J Biol Chem 1997;272: 27787-27795.

13 Taussig R, Iniguez-Lluhi JA, Gilman AG: Inhibition of adenylyl cyclase by Gi alpha. Science 1993;261:218-221.
14 Willoughby D, Cooper DM: Organization and $\mathrm{Ca}^{2+}$ regulation of adenylyl cyclases in cAMP microdomains. Physiol Rev 2007;87: 965-1010.

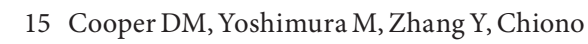
M, Mahey R: Capacitative Ca2+ entry regulates $\mathrm{Ca}^{2+}$-sensitive adenylyl cyclases. Biochem J 1994;297(Pt 3):437-440.

$\checkmark 16$ Lai HL, Yang TH, Messing RO, Ching YH, Lin SC, Chern Y: Protein kinase C inhibits adenylyl cyclase type VI activity during desensitization of the A2a-adenosine receptormediated cAMP response. J Biol Chem 1997; 272:4970-4977.

17 Lin TH, Lai HL, Kao YY, Sun CN, Hwang MJ, Chern Y: Protein kinase C inhibits type VI adenylyl cyclase by phosphorylating the regulatory $\mathrm{N}$ domain and two catalytic $\mathrm{C} 1$ and C2 domains. J Biol Chem 2002;277: 15721-15728.

18 Chen Y, Harry A, Li J, Smit MJ, Bai X, Magnusson R, Pieroni JP, Weng G, Iyengar R: Adenylyl cyclase 6 is selectively regulated by protein kinase A phosphorylation in a region involved in Galphas stimulation. Proc Natl Acad Sci USA 1997;94:14100-14104. 
-19 Salim S, Sinnarajah S, Kehrl JH, Dessauer CW: Identification of RGS2 and type V adenylyl cyclase interaction sites. J Biol Chem 2003;278:15842-15849.

-20 Ostrom RS, Bundey RA, Insel PA: Nitric oxide inhibition of adenylyl cyclase type 6 activity is dependent upon lipid rafts and caveolin signaling complexes. J Biol Chem 2004;279:19846-19853.

21 Tang WJ, Gilman AG: Type-specific regulation of adenylyl cyclase by $G$ protein beta gamma subunits. Science 1991;254:15001503.

22 Choi EJ, Xia Z, Storm DR: Stimulation of the type III olfactory adenylyl cyclase by calcium and calmodulin. Biochemistry 1992;31: 6492-6498.

23 Chiono M, Mahey R, Tate G, Cooper DM: Capacitative $\mathrm{Ca}^{2+}$ entry exclusively inhibits cAMP synthesis in C6-2B glioma cells: evidence that physiologically evoked $\mathrm{Ca} 2+$ entry regulates $\mathrm{Ca}(2+)$-inhibitable adenylyl $\mathrm{cy}$ clase in non-excitable cells. J Biol Chem 1995;270:1149-1155.

-24 Duhe RJ, Nielsen MD, Dittman AH, Villacres EC, Choi EJ, Storm DR: Oxidation of critical cysteine residues of type I adenylyl cyclase by $o$-iodosobenzoate or nitric oxide reversibly inhibits stimulation by calcium and calmodulin. J Biol Chem 1994;269: 7290-7296.

-25 Baker LP, Nielsen MD, Impey S, Metcalf MA, Poser SW, Chan G, Obrietan K, Hamblin MW, Storm DR: Stimulation of type 1 and type $8 \mathrm{Ca} 2+/$ calmodulin-sensitive adenylyl cyclases by the Gs-coupled 5-hydroxytryptamine subtype 5-HT7A receptor. J Biol Chem 1998;273:17469-17476.

26 Wei J, Zhao AZ, Chan GC, Baker LP, Impey S, Beavo JA, Storm DR: Phosphorylation and inhibition of olfactory adenylyl cyclase by CaM kinase II in neurons: a mechanism for attenuation of olfactory signals. Neuron 1998;21:495-504.

-27 Chern Y, Chiou JY, Lai HL, Tsai MH: Regulation of adenylyl cyclase type VI activity during desensitization of the A2a adenosine receptor-mediated cyclic AMP response: role for protein phosphatase $2 \mathrm{~A}$. Mol Pharmacol 1995;48:1-8.

28 Paterson JM, Smith SM, Harmar AJ, Antoni FA: Control of a novel adenylyl cyclase by calcineurin. Biochem Biophys Res Commun 1995:214:1000-1008.

-29 Tan CM, Kelvin DJ, Litchfield DW, Ferguson SS, Feldman RD: Tyrosine kinase-mediated serine phosphorylation of adenylyl cyclase. Biochemistry 2001;40:1702-1709.

-30 Anholt RR: Signal integration in the nervous system: adenylate cyclases as molecular coincidence detectors. Trends Neurosci 1994; 17:37-41.

-31 Nomura M, Vacquier VD: Proteins associated with soluble adenylyl cyclase in sea urchin sperm flagella. Cell Motil Cytoskeleton 2006;63:582-590.
32 Wang D, Hu J, Bobulescu IA, Quill TA, McLeroy P, Moe OW, Garbers DL: A spermspecific $\mathrm{Na}^{+} / \mathrm{H}^{+}$exchanger (sNHE) is critical for expression and in vivo bicarbonate regulation of the soluble adenylyl cyclase (sAC). Proc Natl Acad Sci USA 2007;104:93259330.

33 Paunescu TG, Da Silva N, Russo LM, McKee M, Lu HA, Breton S, Brown D: Association of soluble adenylyl cyclase with the V-ATPase in renal epithelial cells. Am J Physiol Renal Physiol 2008;294:F130-F138.

34 Bakalyar HA, Reed RR: Identification of a specialized adenylyl cyclase that may mediate odorant detection. Science 1990;250: 1403-1406.

-35 Pfeuffer E, Mollner S, Lancet D, Pfeuffer T: Olfactory adenylyl cyclase: identification and purification of a novel enzyme form. J Biol Chem 1989;264:18803-18807.

36 Menco BP, Bruch RC, Dau B, Danho W: Ultrastructural localization of olfactory transduction components: the $G$ protein subunit Golf alpha and type III adenylyl cyclase. Neuron 1992;8:441-453.

37 Col JA, Matsuo T, Storm DR, Rodriguez I: Adenylyl cyclase-dependent axonal targeting in the olfactory system. Development 2007;134:2481-2489.

38 Wang Z, Balet Sindreu C, Li V, Nudelman A Chan GC, Storm DR: Pheromone detection in male mice depends on signaling through the type 3 adenylyl cyclase in the main olfactory epithelium. J Neurosci 2006;26:73757379 .

39 Wong ST, Trinh K, Hacker B, Chan GC, Lowe G, Gaggar A, Xia Z, Gold GH, Storm DR: Disruption of the type III adenylyl cyclase gene leads to peripheral and behavioral anosmia in transgenic mice. Neuron 2000; 27:487-497.

40 Lee KW, Hong JH, Choi IY, Che Y, Lee JK, Yang SD, Song CW, Kang HS, Lee JH, Noh JS, Shin HS, Han PL: Impaired D2 dopamine receptor function in mice lacking type 5 adenylyl cyclase. J Neurosci 2002;22:79317940.

41 Xie F, Garcia MA, Carlson AE, Schuh SM, Babcock DF, Jaiswal BS, Gossen JA, Esposito G, van Duin M, Conti M: Soluble adenylyl cyclase (sAC) is indispensable for sperm function and fertilization. Dev Biol 2006; 296:353-362.

42 Hess KC, Jones BH, Marquez B, Chen Y, Ord TS, Kamenetsky M, Miyamoto C, Zippin JH, Kopf GS, Suarez SS, Levin LR, Williams CJ, Buck J, Moss SB: The 'soluble' adenylyl cyclase in sperm mediates multiple signaling events required for fertilization. Dev Cell 2005;9:249-259.

43 Esposito G, Jaiswal BS, Xie F, Krajnc-Franken MA, Robben TJ, Strik AM, Kuil C, Philipsen RL, van Duin M, Conti M, Gossen JA Mice deficient for soluble adenylyl cyclase are infertile because of a severe sperm-motility defect. Proc Natl Acad Sci USA 2004;101: 2993-2998.
44 Wong ST, Athos J, Figueroa XA, Pineda VV, Schaefer ML, Chavkin CC, Muglia LJ, Storm DR: Calcium-stimulated adenylyl cyclase activity is critical for hippocampus-dependent long-term memory and late phase LTP. Neuron 1999;23:787-798

-45 Conti AC, Maas JW Jr, Muglia LM, Dave BA, Vogt SK, Tran TT, Rayhel EJ, Muglia LJ: Distinct regional and subcellular localization of adenylyl cyclases type 1 and 8 in mouse brain. Neuroscience 2007;146:713-729.

-46 Wang H, Gong B, Vadakkan KI, Toyoda H, Kaang BK, Zhuo M: Genetic evidence for adenylyl cyclase 1 as a target for preventing neuronal excitotoxicity mediated by $\mathrm{N}$ methyl-D-aspartate receptors. J Biol Chem 2007;282:1507-1517.

47 Malik S, Ghosh M, Bonacci TM, Tall GG, Smrcka AV: Ric-8 enhances $G$ protein betagamma-dependent signaling in response to betagamma-binding peptides in intact cells. Mol Pharmacol 2005;68:129-136.

48 Phan HM, Gao MH, Lai NC, Tang T, Hammond HK: New signaling pathways associated with increased cardiac adenylyl cyclase 6 expression: implications for possible congestive heart failure therapy. Trends Cardiovasc Med 2007;17:215-221.

-49 Okumura S, Takagi G, Kawabe J, Yang G, Lee MC, Hong C, Liu J, Vatner DE, Sadoshima J, Vatner SF, Ishikawa Y: Disruption of type 5 adenylyl cyclase gene preserves cardiac function against pressure overload. Proc Natl Acad Sci USA 2003;100:9986-9990.

-50 Okumura S, Vatner DE, Kurotani R, Bai Y, Gao S, Yuan Z, Iwatsubo K, Ulucan C, Kawabe J, Ghosh K, Vatner SF, Ishikawa Y: Disruption of type 5 adenylyl cyclase enhances desensitization of cyclic adenosine monophosphate signal and increases Akt signal with chronic catecholamine stress. Circulation 2007;116:1776-1783.

51 Tang T, Gao MH, Lai NC, Firth AL, Takahashi T, Guo T, Yuan JX, Roth DM, Hammond HK: Adenylyl cyclase type 6 deletion decreases left ventricular function via impaired calcium handling. Circulation 2008; 117:61-69.

52 Lai NC, Roth DM, Gao MH, Tang T, Dalton N, Lai YY, Spellman M, Clopton P, Hammond HK: Intracoronary adenovirus encoding adenylyl cyclase VI increases left ventricular function in heart failure. Circulation 2004;110:330-336.

53 Roth DM, Gao MH, Lai NC, Drumm J, Dalton N, Zhou JY, Zhu J, Entrikin D, Hammond HK: Cardiac-directed adenylyl cyclase expression improves heart function in murine cardiomyopathy. Circulation 1999;99: 3099-3102.

54 Roth DM, Lai NC, Gao MH, Drumm JD, Jimenez J, Feramisco JR, Hammond HK: Indirect intracoronary delivery of adenovirus encoding adenylyl cyclase increases left ventricular contractile function in mice. Am J Physiol Heart Circ Physiol 2004;287:H172H177. 
55 Gao MH, Tang T, Guo T, Sun SQ, Feramisco JR, Hammond HK: Adenylyl cyclase type VI gene transfer reduces phospholamban expression in cardiac myocytes via activating transcription factor 3. J Biol Chem 2004;279: 38797-38802.

56 Iwatsubo K, Minamisawa S, Tsunematsu T, Nakagome M, Toya Y, Tomlinson JE, Umemura S, Scarborough RM, Levy DE, Ishikawa Y: Direct inhibition of type 5 adenylyl cyclase prevents myocardial apoptosis without functional deterioration. J Biol Chem 2004;279:40938-40945.

57 Packer M, Carver JR, Rodeheffer RJ, Ivanhoe RJ, DiBianco R, Zeldis SM, Hendrix GH, Bommer WJ, Elkayam U, Kukin ML, et al: Effect of oral milrinone on mortality in severe chronic heart failure. The PROMISE Study Research Group. N Engl J Med 1991; 325:1468-1475.

58 Dorn GW 2nd, Tepe NM, Lorenz JN, Koch WJ, Liggett SB: Low- and high-level transgenic expression of beta2-adrenergic receptors differentially affect cardiac hypertrophy and function in Galphaq-overexpressing mice. Proc Natl Acad Sci USA 1999;96:64006405.

-59 Tang T, Gao MH, Roth DM, Guo T, Hammond HK: Adenylyl cyclase type VI corrects cardiac sarcoplasmic reticulum calcium uptake defects in cardiomyopathy. Am J Physiol Heart Circ Physiol 2004;287:H1906H1912.

-60 Chou JL, Huang CL, Lai HL, Hung AC, Chien CL, Kao YY, Chern Y: Regulation of type VI adenylyl cyclase by Snapin, a SNAP25-binding protein. J Biol Chem 2004; 279:46271-46279.

-61 Zissimopoulos S, West DJ, Williams AJ, Lai FA: Ryanodine receptor interaction with the SNARE-associated protein snapin. J Cell Sci 2006;119:2386-2397.

-62 Dessauer CW, Tesmer JJ, Sprang SR, Gilman AG: Identification of a Gialpha binding site on type V adenylyl cyclase. J Biol Chem 1998; 273:25831-25839.

63 Steiner D, Saya D, Schallmach E, Simonds WF, Vogel Z: Adenylyl cyclase type-VIII activity is regulated by $\mathrm{G}$ (betagamma) subunits. Cell Signal 2006;18:62-68.

64 Weitmann S, Schultz G, Kleuss C: Adenylyl cyclase type II domains involved in Gbetagamma stimulation. Biochemistry 2001;40: 10853-10858.

65 Diel S, Klass K, Wittig B, Kleuss C: Gbetagamma activation site in adenylyl cyclase type II: adenylyl cyclase type III is inhibited by Gbetagamma. J Biol Chem 2006;281:288294.

66 Wittpoth C, Scholich K, Yigzaw Y, Stringfield TM, Patel TB: Regions on adenylyl cyclase that are necessary for inhibition of activity by beta gamma and G(ialpha) subunits of heterotrimeric $\mathrm{G}$ proteins. Proc Natl Acad Sci USA 1999;96:9551-9556.
67 Chen J, DeVivo M, Dingus J, Harry A, Li J, Sui J, Carty DJ, Blank JL, Exton JH, Stoffel $\mathrm{RH}$, et al: A region of adenylyl cyclase 2 critical for regulation by $\mathrm{G}$ protein beta gamma subunits. Science 1995;268:1166-1169.

68 Yan K, Gautam N: A domain on the G protein beta subunit interacts with both adenylyl cyclase 2 and the muscarinic atrial potassium channel. J Biol Chem 1996;271: 17597-17600.

-69 Bayewitch ML, Avidor-Reiss T, Levy R, Pfeuffer T, Nevo I, Simonds WF, Vogel Z: Inhibition of adenylyl cyclase isoforms $\mathrm{V}$ and VI by various Gbetagamma subunits. FASEB J 1998;12:1019-1025.

70 Premont RT, Chen J, Ma HW, Ponnapalli M, Iyengar R: Two members of a widely expressed subfamily of hormone-stimulated adenylyl cyclases. Proc Natl Acad Sci USA 1992;89:9809-9813.

71 Gao X, Sadana R, Dessauer CW, Patel TB: Conditional stimulation of type $\mathrm{V}$ and VI adenylyl cyclases by $\mathrm{G}$ protein betagamma subunits. J Biol Chem 2007;282:294-302.

72 Lai HL, Lin TH, Kao YY, Lin WJ, Hwang MJ, Chern Y: The N terminus domain of type VI adenylyl cyclase mediates its inhibition by protein kinase C. Mol Pharmacol 1999;56: 644-650.

73 Scholich K, Pierre S, Patel TB: Protein associated with Myc (PAM) is a potent inhibitor of adenylyl cyclases. J Biol Chem 2001;276: 47583-47589.

74 Roy AA, Baragli A, Bernstein LS, Hepler JR, Hebert TE, Chidiac P: RGS2 interacts with Gs and adenylyl cyclase in living cells. Cell Signal 2006;18:336-348.

75 Bauman AL, Soughayer J, Nguyen BT, Willoughby D, Carnegie GK, Wong W, Hoshi N, Langeberg LK, Cooper DM, Dessauer CW, Scott JD: Dynamic regulation of cAMP synthesis through anchored PKA-adenylyl cyclase V/VI complexes. Mol Cell 2006;23: 925-931.

76 Hoshi N, Langeberg LK, Scott JD: Distinct enzyme combinations in AKAP signalling complexes permit functional diversity. Nat Cell Biol 2005;7:1066-1073.

$>77$ Iwami G, Kawabe J, Ebina T, Cannon PJ, Homcy CJ, Ishikawa Y: Regulation of adenylyl cyclase by protein kinase A. J Biol Chem 1995;270:12481-12484.

$78 \mathrm{Gu}$ C, Cooper DM: Calmodulin-binding sites on adenylyl cyclase type VIII. J Biol Chem 1999;274:8012-8021.

79 Wang SC, Lai HL, Chiu YT, Ou R, Huang CL, Chern Y: Regulation of type V adenylate cyclase by Ric8a, a guanine nucleotide exchange factor. Biochem J 2007;406:383388.

80 Chou JL, Huang CL, Lai HL, Hung AC, Chien CL, Kao YY, Chern Y: Regulation of type VI adenylyl cyclase by Snapin, a SNAP25-binding protein. J Biol Chem 2004; 279:46271-46279.
81 Crossthwaite AJ, Ciruela A, Rayner TF, Cooper DM: A direct interaction between the $\mathrm{N}$ terminus of adenylyl cyclase AC8 and the catalytic subunit of protein phosphatase $2 \mathrm{~A}$. Mol Pharmacol 2006;69:608-617.

82 Tall GG, Krumins AM, Gilman AG: Mammalian Ric-8A (synembryn) is a heterotrimeric Galpha protein guanine nucleotide exchange factor. J Biol Chem 2003;278:83568362.

83 Schinke M: Region of the heart between the LAD artery and the apex on a mouse with myocardial infarction (the infarcted area). NCBI GEO 2003;GSM12354-12356.

>84 Kao YY, Lai HL, Hwang MJ, Chern Y: An important functional role of the $\mathrm{N}$ terminus domain of type VI adenylyl cyclase in $\mathrm{G} \alpha_{\mathrm{i}}$-mediated inhibition. J Biol Chem 2004;279: 34440-34448.

85 Ilardi JM, Mochida S, Sheng ZH: Snapin: a SNARE-associated protein implicated in synaptic transmission. Nat Neurosci 1999;2: 119-124.

>86 Chheda MG, Ashery U, Thakur P, Rettig J, Sheng ZH: Phosphorylation of Snapin by PKA modulates its interaction with the SNARE complex. Nat Cell Biol 2001;3:331338.

-87 Thakur P, Stevens DR, Sheng ZH, Rettig J: Effects of PKA-mediated phosphorylation of Snapin on synaptic transmission in cultured hippocampal neurons. J Neurosci 2004;24: 6476-6481.

-88 Tian JH, Wu ZX, Unzicker M, Lu L, Cai Q, Li C, Schirra C, Matti U, Stevens D, Deng C, Rettig J, Sheng ZH: The role of Snapin in neurosecretion: Snapin knock-out mice exhibit impaired calcium-dependent exocytosis of large dense-core vesicles in chromaffin cells. J Neurosci 2005;25:10546-10555.

89 Buxton P, Zhang XM, Walsh B, Sriratana A, Schenberg I, Manickam E, Rowe T: Identification and characterization of Snapin as a ubiquitously expressed SNARE-binding protein that interacts with SNAP23 in nonneuronal cells. Biochem J 2003;375:433-440.

90 Vites O, Rhee JS, Schwarz M, Rosenmund C, Jahn R: Reinvestigation of the role of snapin in neurotransmitter release. J Biol Chem 2004;279:26251-26256

-91 Rüder C, Reimer T, Delgado-Martinez I, Hermosilla R, Engelsberg A, Nehring R, Dörken B, Rehm A: EBAG9 adds a new layer of control on large dense-core vesicle exocytosis via interaction with Snapin. Mol Biol Cell 2005; 16:1245-1257.

92 Starcevic M, Dell'Angelica EC: Identification of snapin and three novel proteins (BLOS1, BLOS2 and BLOS3/reduced pigmentation) as subunits of biogenesis of lysosome-related organelles complex-1 (BLOC1). J Biol Chem 2004;279:28393-28401.

93 Krapivinsky G, Mochida S, Krapivinsky L, Cibulsky SM, Clapham DE: The TRPM7 ion channel functions in cholinergic synaptic vesicles and affects transmitter release. Neuron 2006;52:485-496. 
94 Hunt RA, Edris W, Chanda PK, Nieuwenhuijsen B, Young KH: Snapin interacts with the $\mathrm{N}$-terminus of regulator of $\mathrm{G}$ protein signaling 7. Biochem Biophys Res Commun 2003;303:594-599.

95 Schaaf CP, Benzing J, Schmitt T, Erz DH, Tewes M, Bartram CR, Janssen JW: Novel interaction partners of the TPR/MET tyrosine kinase. FASEB J 2005;19:267-269.

$\checkmark 96$ Talbot K, Cho DS, Ong WY, Benson MA, Han LY, Kazi HA, Kamins J, Hahn CG, Blake DJ, Arnold SE: Dysbindin-1 is a synaptic and microtubular protein that binds brain Snapin. Hum Mol Genet 2006;15: 3041-3054.

$\checkmark 97$ Wolff S, Stoter M, Giamas G, Piesche M, Henne-Bruns D, Banting G, Knippschild $\mathrm{U}$ : Casein kinase 1 delta (CK1delta) interacts with the SNARE associated protein snapin. FEBS Lett 2006;580:6477-6484.

$\checkmark 98$ Mistry AC, Mallick R, Fröhlich O, Klein JD, Rehm A, Chen G, Sands JM: The UT-A1 urea transporter interacts with snapin, a SNARE-associated protein. J Biol Chem 2007;282:30097-30106.

$\checkmark 9$ Bao Y, Lopez JA, James DE, Hunziker W: Snapin interacts with the Exo70 subunit of the exocyst and modulates GLUT4 trafficking. J Biol Chem 2008;283:324-331.

-100 Suzuki F, Morishima S, Tanaka T, Muramatsu I: Snapin, a new regulator of receptor signaling, augments alpha1A-adrenoceptor-operated calcium influx through TRPC6. J Biol Chem 2007;282:2956329573.

-101 Raymond LA, Blackstone CD, Huganir RL: Phosphorylation and modulation of recombinant gluR6 glutamate receptors by cAMP-dependent protein kinase. Nature 1993;361:637-641.

-102 Roche KW, O’Brien RJ, Mammen AL, Bernhardt J, Huganir RL: Characterization of multiple phosphorylation sites on the AMPA receptor GluR1 subunit. Neuron 1996;16:1179-1188.

- 103 Esteban JA, Shi SH, Wilson C, Nuriya M, Huganir RL, Malinow R: PKA phosphorylation of AMPA receptor subunits controls synaptic trafficking underlying plasticity. Nat Neurosci 2003;6:136-143.

-104 Man HY, Sekine-Aizawa Y, Huganir RL: Regulation of \{alpha\}-amino-3-hydroxy-5methyl-4-isoxazolepropionic acid receptor trafficking through PKA phosphorylation of the Glu receptor 1 subunit. Proc Natl Acad Sci USA 2007;104:3579-3584.

- 105 Uehara A, Yasukochi M, Mejia-Alvarez R, Fill M, Imanaga I: Gating kinetics and ligand sensitivity modified by phosphorylation of cardiac ryanodine receptors. Pflügers Arch 2002;444:202-212.

-106 Cayouette S, Boulay G: Intracellular trafficking of TRP channels. Cell Calcium 2007;42:225-232.
107 Singh BB, Lockwich TP, Bandyopadhyay BC, Liu X, Bollimuntha S, Brazer SC, Combs C, Das S, Leenders AG, Sheng ZH, Knepper MA, Ambudkar SV, Ambudkar IS: VAMP2-dependent exocytosis regulates plasma membrane insertion of TRPC3 channels and contributes to agonist-stimulated $\mathrm{Ca}^{2+}$ influx. Mol Cell 2004;15:635646.

108 Redondo PC, Harper AG, Salido GM, Pariente JA, Sage SO, Rosado JA: A role for SNAP-25 but not VAMPs in store-mediated $\mathrm{Ca}^{2+}$ entry in human platelets. J Physiol 2004;558:99-109.

109 Birnbaumer L, Boulay G, Brown D, Jiang M, Dietrich A, Mikoshiba K, Zhu X, Qin N: Mechanism of capacitative $\mathrm{Ca}^{2+}$ entry (CCE): interaction between IP3 receptor and TRP links the internal calcium storage compartment to plasma membrane CCE channels. Recent Prog Horm Res 2000;55: 127-162.

110 Zhu X, Jiang M, Peyton M, Boulay G, Hurst R, Stefani E, Birnbaumer L: TRP, a novel mammalian gene family essential for agonist-activated capacitative $\mathrm{Ca}^{2+}$ entry. Cell 1996;85:661-671.

11 Kiselyov K, Kim JY, Zeng W, Muallem S: Protein-protein interaction and functionTRPC channels. Pflügers Arch 2005;451: 116-124.

112 Beazely MA, Watts VJ: Galphaq-coupled receptor signaling enhances adenylate cyclase type 6 activation. Biochem Pharmacol 2005;70:113-120.

113 Fagan KA, Mahey R, Cooper DM: Functional co-localization of transfected $\mathrm{Ca}^{2+}$ stimulable adenylyl cyclases with capacitative $\mathrm{Ca}^{2+}$ entry sites. J Biol Chem 1996;271: 12438-12444.

114 Smith KE, Gu C, Fagan KA, Hu B, Cooper DM: Residence of adenylyl cyclase type 8 in caveolae is necessary but not sufficient for regulation by capacitative $\mathrm{Ca}^{2+}$ entry. J Biol Chem 2002;277:6025-6031.

115 Krupinski J, Coussen F, Bakalyar HA, Tang WJ, Feinstein PG, Orth K, Slaughter C, Reed RR, Gilman AG: Adenylyl cyclase amino acid sequence: possible channel- or transporter-like structure. Science 1989; 244:1558-1564.

116 Wang H, Ferguson GD, Pineda VV, Cundiff PE, Storm DR: Overexpression of type-1 adenylyl cyclase in mouse forebrain enhances recognition memory and LTP. Nat Neurosci 2004;7:635-642.

117 Wu ZL, Thomas SA, Villacres EC, Xia Z, Simmons ML, Chavkin C, Palmiter RD, Storm DR: Altered behavior and long-term potentiation in type I adenylyl cyclase mutant mice. Proc Natl Acad Sci USA 1995;92: 220-224.

118 Villacres EC, Wong ST, Chavkin C, Storm DR: Type I adenylyl cyclase mutant mice have impaired mossy fiber long-term potentiation. J Neurosci 1998;18:3186-3194.
119 Gong B, Wang H, Gu S, Heximer SP, Zhuo $M$ : Genetic evidence for the requirement of adenylyl cyclase 1 in synaptic scaling of forebrain cortical neurons. Eur J Neurosci 2007;26:275-288.

120 Zachariou V, Liu R, LaPlant Q, Xiao G, Renthal W, Chan GC, Storm DR, Aghajanian G, Nestler EJ: Distinct roles of adenylyl cyclases 1 and 8 in opiate dependence: behavioral, electrophysiological and molecular studies. Biol Psychiatry 2008;63: 1013-1021.

121 Wei F, Qiu CS, Kim SJ, Muglia L, Maas JW, Pineda VV, Xu HM, Chen ZF, Storm DR, Muglia LJ, Zhuo M: Genetic elimination of behavioral sensitization in mice lacking calmodulin-stimulated adenylyl cyclases. Neuron 2002;36:713-726.

122 Abdel-Majid RM, Leong WL, Schalkwyk LC, Smallman DS, Wong ST, Storm DR, Fine A, Dobson MJ, Guernsey DL, Neumann PE: Loss of adenylyl cyclase I activity disrupts patterning of mouse somatosensory cortex. Nat Genet 1998;19:289-291.

123 Fukuhara C, Liu C, Ivanova TN, Chan GC, Storm DR, Iuvone PM, Tosini G: Gating of the camp signaling cascade and melatonin synthesis by the circadian clock in mammalian retina. J Neurosci 2004;24:18031811.

124 Livera G, Xie F, Garcia MA, Jaiswal B, Chen J, Law E, Storm DR, Conti M: Inactivation of the mouse adenylyl cyclase 3 gene disrupts male fertility and spermatozoon function. Mol Endocrinol 2005;19:12771290.

125 Iwamoto T, Okumura S, Iwatsubo K, Kawabe J, Ohtsu K, Sakai I, Hashimoto Y, Izumitani A, Sango K, Ajiki K, Toya Y, Umemura S, Goshima Y, Arai N, Vatner SF, Ishikawa Y: Motor dysfunction in type 5 adenylyl cyclase-null mice. J Biol Chem 2003;278:16936-16940.

126 Okumura S, Kawabe J, Yatani A, Takagi G, Lee MC, Hong C, Liu J, Takagi I, Sadoshima J, Vatner DE, Vatner SF, Ishikawa Y: Type 5 adenylyl cyclase disruption alters not only sympathetic but also parasympathetic and calcium-mediated cardiac regulation. Circ Res 2003;93:364-371.

127 Kim KS, Lee KW, Lee KW, Im JY, Yoo JY, Kim SW, Lee JK, Nestler EJ, Han PL: Adenylyl cyclase type 5 (AC5) is an essential mediator of morphine action. Proc Natl Acad Sci USA 2006;103:3908-3913.

128 Kim KS, Kim J, Back SK, Im JY, Na HS, Han PL: Markedly attenuated acute and chronic pain responses in mice lacking adenylyl cyclase-5. Genes Brain Behav 2007;6:120127.

129 Yan L, Vatner DE, O’Connor JP, Ivessa A, Ge H, Chen W, Hirotani S, Ishikawa Y, Sadoshima J, Vatner SF: Type 5 adenylyl cyclase disruption increases longevity and protects against stress. Cell 2007;130:247258. 
130 Zhang M, Moon C, Chan GC, Yang L, Zheng F, Conti AC, Muglia L, Muglia LJ, Storm DR, Wang H: Ca-stimulated type 8 adenylyl cyclase is required for rapid acquisition of novel spatial information and for working/episodic-like memory. J Neurosci 2008;28:4736-4744.

$>131$ Schaefer ML, Wong ST, Wozniak DF, Muglia LM, Liauw JA, Zhuo M, Nardi A, Hartman RE, Vogt SK, Luedke CE, Storm DR, Muglia LJ: Altered stress-induced anxiety in adenylyl cyclase type VIII-deficient mice. J Neurosci 2000;20:4809-4820.

132 Marquez B, Suarez SS: Soluble adenylyl cyclase is required for activation of sperm but does not have a direct effect on hyperactivation. Reprod Fertil Dev 2008;20:247-252.
133 Sinclair ML, Wang XY, Mattia M, Conti M, Buck J, Wolgemuth DJ, Levin LR: Specific expression of soluble adenylyl cyclase in male germ cells. Mol Reprod Dev 2000;56: 6-11.

134 Gao X, Patel TB: Histidine residues 912 and 913 in protein associated with Myc are necessary for the inhibition of adenylyl cyclase activity. Mol Pharmacol 2005;67:42-49.

135 Morenilla-Palao C, Planells-Cases R, Garcia-Sanz N, Ferrer-Montiel A: Regulated exocytosis contributes to protein kinase C potentiation of vanilloid receptor activity. J Biol Chem 2004;279:25665-25672.
136 Chen M, Lucas KG, Akum BF, Balasingam G, Stawicki TM, Provost JM, Riefler GM, Jornsten RJ, Firestein BL: A novel role for snapin in dendrite patterning: interaction with cypin. Mol Biol Cell 2005;16:51035114.

137 Fukui K, Yang Q, Cao Y, Takahashi N, Hatakeyama $\mathrm{H}$, Wang $\mathrm{H}$, Wada J, Zhang Y, Marselli L, Nammo T, Yoneda K, Onishi M, Higashiyama S, Matsuzawa Y, Gonzalez FJ, Weir GC, Kasai H, Shimomura I, Miyagawa J, Wollheim CB, Yamagata K: The HNF-1 target collectrin controls insulin exocytosis by SNARE complex formation. Cell Metab 2005;2:373-384.

138 Yuan X, Shan Y, Zhao Z, Chen J, Cong Y: Interaction between Snapin and G-CSF receptor. Cytokine 2006;33:219-225. 